\title{
Gammlung
}

\section{feuerpolizeillid)er bor/drúften}

für

\section{Baupolizeí und feureda)au in Bayern}

\author{
Egerausgegeben von
}

\section{Otto Gofmíller}

Beandver/fdezungerat I. KI.

bei der Bayerifden ber/lderungofammer in mänden

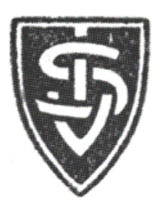

$\mathfrak{m}$ uี $\mathfrak{n}$ ต) $\mathfrak{n} 1929$

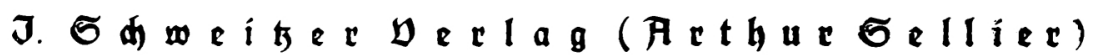




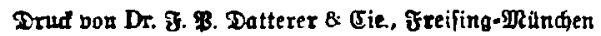

